\title{
Mutagenic Effectiveness and Efficiency of Gamma Rays and EMS on Cape Gooseberry (Physalis peruviana L.)
}

\author{
Alok Kumar Gupta ${ }^{1 *}$, S.P. Singh ${ }^{1}$, Manvendra Singh ${ }^{2}$ and E.S. Marboh ${ }^{2}$ \\ ${ }^{1}$ Institute of Agricultural Sciences, Banaras Hindu University, Varanasi- 221005 U.P., India \\ ${ }^{2}$ ICAR-National research Centre on Litchi, Muzaffarpur-842002, Bihar, India \\ *Corresponding author
}

\section{A B S T R A C T}

\section{Keywords \\ Cape gooseberry, EMS, Effectiveness, Gamma rays, Mutagenic efficiency \\ Article Info \\ Accepted: 26 January 2018 Available Online: 10 February 2018}

The present investigation was carried out to find the efficiency and effectiveness of various mutagenic treatments of gamma rays and EMS on cape gooseberry. Genetically pure, uniform and dry seeds of cape gooseberry were subjected to 2, 5, 10, 15 and $20 \mathrm{kR}$ doses of gamma rays and $0.02,0.03,0.04$ and $0.05 \mathrm{M}$ concentration of ethyl methane sulfonate along with control. Chlorophyll mutation, biological damages and viable mutant frequency was recorded in M1 and M2 generation. Highest mutation frequency $3.17 \%$ was observed in $0.02 \mathrm{M}$ EMS followed by $0.03 \mathrm{M}$ EMS $2.42 \%$ and the effectiveness of EMS treatments ranged from 1.09 to 4.55 and $2 \mathrm{kR}$ and $0.02 \mathrm{M}$ EMS were the most efficient treatments. The higher doses of both mutagen lead to lethal injury and sterility.

\section{Introduction}

The cape gooseberry (Physalis peruviana L.) is a member of Solanaceae family. It belongs to the genus Physalis with approximately 80 species cultivated in Mexico and Guatemala and originating from Mesoamerica (Menzel, 1951 and Bukasov, 1963). It is known as rasbhari in India, goldenberry in European countries and uchuva in Colombia (Puente et al., 2011). The fruit is a juicy berry with rounded shape and a diameter between 1.25 to $2.65 \mathrm{~cm}, 4$ to12 g weight along with 100 to 200 small seed. Calyx protect the fruit from insects, disease, birds and adverse conditions. Cape gooseberry is an economically useful crop, especially in Colombia, where it is one of the most important exotic fruit. It is also important in South Africa and Kenya where there have been active breeding programmes. It is used as a fresh fruit or, more commonly, as the basis for jams preparation. It is high in ascorbic acid (Barcia et al., 2010).

Cape gooseberry has a very narrow genetic base so it is difficult to produce superior variety. So Mutational breeding is one of the effective tools for improvement of cape gooseberry. Mutation breeding is an effective tools for improvement of crop which having narrow genetic base such as cape gooseberry. Among different mutagenic agent gamma irradiation and EMS had been used successfully with several solanaceous crop for 
creating variability. The usefulness of a mutagen in mutation breeding depends not only on its mutagenic effectiveness (mutations per unit dose of mutagens), but also its mutagenic efficiency (mutation in relation to undesirable changes like sterility, lethality, injury etc.). The selection of effective and efficient mutagens is very essential to recover a high frequency and spectrum of desirable mutations. Gamma rays and EMS (Ethyl Methane Sulfonate) are widely used mutagen for induction of viable mutant and mutational studies. Gamma irradiation as mutagen can induce useful as well as harmful mutation in plants (Gupta, 1996). Gamma rays are known to influence plant growth and development by inducing cytological, genetical, biochemical, physiological and morphogenetic changes in cells and tissues. The selection of effective and efficient mutagens is very essential to recover a high frequency and spectrum of desirable mutations (Solanki \& Sharma, 1994) and (Mahabatra, 1983).Therefore, present experiment was carried out to apply various gamma ray doses and different concentration of ethyl methanesulfonate (EMS) were undertaken in Physalis peruviana $\mathrm{L}$.

\section{Materials and Methods}

\section{Study site}

The present investigation was carried out at the Horticulture Research Farm, Department of Horticulture, Banaras Hindu University, Varanasi $\left(25^{\circ} 10^{\prime}\right.$ North latitude and $83^{\circ} 04^{\prime}$ East longitudes with an altitude of 123.23 meter above the mean sea level), Uttar Pradesh.

\section{Study materials}

Genetically pure, uniform and dry seeds $(10 \%$ moisture content) of cape gooseberry were taken for induction of mutation by using gamma irradiation and EMS. The gamma treatments were given by using the ${ }^{60} \mathrm{Co}$ Gamma cell. Ethyl methane sulphonate $\left(\mathrm{CH}_{3}\right.$ $\left.\mathrm{SO}_{2} \quad \mathrm{OC}_{2} \mathrm{H}_{5}\right)$ manufactured from the Sigma Chemical Company, USA was used for treating the seeds.

Healthy seeds packed in moist germination paper were selected for each treatment in the gamma chamber at 2, 5, 10, 15 and $20 \mathrm{kR}$ doses of gamma rays in ${ }^{60} \mathrm{CO}$ gamma source (irradiation source capacity to release $3000 \mathrm{Ci}$ delivery $7200 \mathrm{r} / \mathrm{min}$ ). For EMS treatment, the seeds were pre-soaked in double distilled water for 12 hours. The pre-soaked seeds were treated with 0.02, 0.03, 0.04 and 0.05 M EMS freshly prepared solution for 6 hours.

After the EMS treatment, the treated seeds were washed thoroughly in running tap water for $4 \mathrm{~h}$ to terminate the residual effect of the mutagenic chemicals. After the completion of the treatment all treated seeds were sown immediately in the field along with their respective controls to obtain the $\mathrm{M}_{1}$ generation. Mutagenic effectiveness is defined as a measure of frequency of mutation induced by a unit of mutagen, while mutagenic efficiency gives an idea of the proportion of mutation in relation to deleterious effects like lethality, injury and sterility. The mutagenic efficiency and effectiveness were measure by the formula suggested by Konzak et al., (1965). The chlorophyll and macromutations were also scored treatment wise to study the mutagenic effectiveness and efficiency of each treatment. Observation on biological abnormalities such as injury and lethality in $\mathrm{M}_{1}$ generation and chlorophyll mutation frequencies in M2 generation were recorded which was used to determine effectiveness and efficiency of both mutagen.

Mutation effectiveness

Rate of mutation (Mp)

(Gamma rays) = ---------------------------- × 100 Dose of gray $(\mathrm{Gy})$ 
Rate of mutation (Mp)

Mutation effectiveness (EMS) $=$ $\times 100$

Concentration $\times$ Duration of treatment

Rate of mutation (Mp)

Mutation efficiency =

Biological damage of M1 generation

Biological damage: For measuring the biological damage, three different criteria were used;

Injury - i.e., percentage of reduction in seedling height $(\mathrm{Mp} / \mathrm{I})$

Sterility - i.e., percentage of reduction in pollen fertility $(\mathrm{Mp} / \mathrm{S})$

Meiotic abnormalities - i.e., percentage of meiotic abnormalities $(\mathrm{Mp} / \mathrm{Me})$

\section{Chlorophyll mutation}

All the treated populations were screened carefully for the frequency and spectrum of chlorophyll mutations. Lethal chlorophyll mutations were scored within 10 day old seedlings, whereas viable chlorophyll mutations were scored throughout the life cycle of plants. They were identified and classified according to Gustafsson (1940). Chlorophyll mutation frequency in term of number of mutants per $1000 \mathrm{M}_{2}$ plants were calculated.

Total number of mutant seedlings Mutation frequency $(\%)=-------------\times 100$

Total number of $\mathrm{M}_{2}$ seedlings

\section{Results and Discussion}

\section{Chlorophyll mutant}

Macromutations described the genetic effects of various mutagens. Chlorophyll mutations are employed as markers for the evaluation of gene action of mutagenic factors in inducing mutation and the appearance of more number of viridis type mutations could be attributed to the involvement of polygenes in chlorophyll formation (Gaul, 1964). Chlorophyll mutations provide most dependable indices for the evaluation of genetic effects of mutagenic treatments in various crops (Gautam et al., 1992). The frequency of chlorophyll mutants in $\mathrm{M}_{2}$ generation mainly indicates dependable measure of genetic effects in mutagens (Nilan and Konzak, 1961).

In this study, the highest mutation frequency $3.17 \%$ was observed in $0.02 \mathrm{M}$ EMS followed by $2.42 \%$ in 0.03 M EMS. However, the lower dose of EMS was found to be more effective than gamma rays treatments (Table 1). Higher frequencies of chlorophyll mutation with lower doses of mutagen were reported in different crops by Yamaguchi et al., (2009) and Pawar et al., (2010). The decrease in chlorophyll mutation frequency at the highest doses of mutagen may be attributed to saturation in the mutational events which result in the elimination of the mutant cells during growth. The decrease in chlorophyll mutation frequency as observed at the higher doses of mutagens may be attributed to saturation in the mutational events which may result in the elimination of the mutant cells during growth. Swaminathan (1969) explained that the high frequency of chlorophyll mutations in EMS treatment is perhaps due to preferential action of EMS on genes for chlorophyll development located near the centromeres.

\section{Viable mutant}

In the present study, the highest frequency was noted in EMS treated population (3.17\%) and the lowest with gamma rays treatments $(1.31 \%)$. The spectrum of mutations induced by EMS was comparatively wider than that of gamma rays (Table 2). 
Table.1 Frequency and spectrum of chlorophyll mutation

\begin{tabular}{|c|c|c|c|c|c|c|c|}
\hline Treatments & $\begin{array}{c}\text { Number } \\
\text { of } \mathrm{M} 2 \\
\text { seedling } \\
\text { examined }\end{array}$ & Albina & Chlorina & Xantha & Viridis & Total chlorophyll mutants & $\begin{array}{l}\text { Mutation } \\
\text { frequency } \\
(\%)\end{array}$ \\
\hline \multicolumn{8}{|l|}{ Gamma rays } \\
\hline 2 kR & 775 & 8 & 3 & 2 & 3 & 16 & 2.06 \\
\hline $5 \mathrm{kR}$ & 726 & 9 & 5 & 2 & 1 & 17 & 2.34 \\
\hline $10 \mathrm{kR}$ & 650 & 5 & 2 & 2 & 2 & 11 & 1.69 \\
\hline $15 \mathrm{kR}$ & 629 & 6 & 2 & - & 1 & 9 & 1.43 \\
\hline $20 \mathrm{kR}$ & 591 & 3 & 3 & 1 & 0 & 7 & 1.18 \\
\hline \multicolumn{8}{|l|}{ EMS } \\
\hline $0.02 \mathrm{M}$ & 819 & 14 & 6 & 3 & 3 & 26 & 3.17 \\
\hline $0.03 \mathrm{M}$ & 783 & 9 & 5 & 4 & 1 & 19 & 2.42 \\
\hline $0.04 \mathrm{M}$ & 678 & 7 & 2 & 1 & 2 & 12 & 1.76 \\
\hline $0.05 \mathrm{M}$ & 612 & 8 & 3 & 0 & 1 & 12 & 1.96 \\
\hline Control & 893 & - & - & - & - & - & - \\
\hline
\end{tabular}

Table.2 Frequency of viable mutants in $\mathrm{M}_{2}$ generation

\begin{tabular}{|c|c|c|c|}
\hline Treatments & $\begin{array}{c}\text { Number of M2 Seedlings } \\
\text { Examined }\end{array}$ & $\begin{array}{c}\text { Showing Viable } \\
\text { Mutants }\end{array}$ & $\begin{array}{l}\text { Mutation } \\
\text { Frequency } \\
(\%)\end{array}$ \\
\hline \multicolumn{4}{|l|}{ Gamma rays } \\
\hline $2 \mathrm{kR}$ & 152 & 2 & 1.31 \\
\hline $5 \mathrm{kR}$ & 144 & 4 & 2.78 \\
\hline $10 \mathrm{kR}$ & 128 & 2 & 1.56 \\
\hline $15 \mathrm{kR}$ & 102 & 4 & 3.92 \\
\hline $20 \mathrm{kR}$ & 92 & 2 & 2.17 \\
\hline \multicolumn{4}{|l|}{ EMS } \\
\hline $0.02 \mathrm{M}$ & 146 & 6 & 4.1 \\
\hline $0.03 \mathrm{M}$ & 130 & 4 & 3.07 \\
\hline $0.04 \mathrm{M}$ & 110 & 2 & 1.81 \\
\hline $0.05 \mathrm{M}$ & 98 & 2 & 2.04 \\
\hline Control & 188 & - & - \\
\hline
\end{tabular}


Table.3 Mutagenic effectiveness and efficiency based on viable mutants

\begin{tabular}{|c|c|c|c|c|c|c|}
\hline $\begin{array}{c}\text { Treatm } \\
\text { ents }\end{array}$ & $\begin{array}{l}\text { \% Survival } \\
\text { reduction at } \\
\text { 30 DAT } \\
\text { (lethality) }\end{array}$ & $\begin{array}{l}\text { Height reduction } \\
\text { injury \% (I) }\end{array}$ & $\begin{array}{l}\text { Mutation } \\
\text { Frequency } \\
\text { (M) }\end{array}$ & $\begin{array}{c}\text { Effectiveness M } \\
\times 100 / \mathrm{kR}(\text { or }) \mathrm{C} \\
\times \mathrm{T}\end{array}$ & $\begin{array}{l}\text { Efficiency } \\
M / L \times 100\end{array}$ & $\begin{array}{l}\text { Efficiency } \\
M / I \times 100\end{array}$ \\
\hline \multicolumn{7}{|l|}{$\begin{array}{l}\text { Gamma } \\
\text { rays }\end{array}$} \\
\hline $2 \mathrm{kR}$ & 13.21 & 5.99 & 1.31 & 6.55 & 9.91 & 21.87 \\
\hline $5 \mathrm{kR}$ & 18.7 & 18.54 & 2.78 & 5.55 & 14.87 & 14.99 \\
\hline $10 \mathrm{kR}$ & 27.21 & 21.51 & 1.56 & 1.56 & 5.73 & 7.25 \\
\hline $15 \mathrm{kR}$ & 29.56 & 28.87 & 3.92 & 2.61 & 13.26 & 13.58 \\
\hline $20 \mathrm{kR}$ & 33.82 & 39.01 & 2.17 & 1.09 & 6.42 & 5.56 \\
\hline \multicolumn{7}{|l|}{ EMS } \\
\hline $0.02 \mathrm{M}$ & 8.29 & 12.5 & 2.73 & 4.55 & 32.94 & 21.84 \\
\hline $0.03 \mathrm{M}$ & 12.32 & 30.05 & 3.07 & 3.41 & 24.92 & 10.22 \\
\hline $0.04 \mathrm{M}$ & 24.08 & 47.83 & 1.81 & 1.51 & 7.52 & 3.78 \\
\hline $0.05 \mathrm{M}$ & 31.47 & 48.73 & 2.04 & 4.08 & 19.45 & 12.56 \\
\hline
\end{tabular}

Reduction in internode length was mainly responsible for dwarfness. The mutant plants which exhibited prostrate growth habit had long internodes and weak stem which are in agreement with the findings in Vigna radiata (Wani et al., 2011).

\section{Mutagenic effectiveness and efficiency}

Mutagenic effectiveness is a measure of the frequency of mutation induced by a unit dose of mutagen while mutagenic efficiency represents the proportion of mutation in relation to the associated undesirable biological effects, such as chromosomal aberration, lethality and sterility induced by mutagen in question (Konzak et al., 1965). The effectiveness decreased with increasing dose or concentration. Increasing doses of EMS or Gamma rays decreased the values obtained for all the biological criteria for M1 generation. The reduction in biological criteria may be attributed to a drop in the auxin level (Gordon \& Webber, 1955) and inhibition of auxin synthesis (Skoog, 1935). EMS was found to be more effective than gamma rays and combined treatments. Data on effectiveness and efficiency of various mutagenic treatments calculated on the basis of the frequency of chlorophyll mutations and biological damage are presented in Table 3. It was found that effectiveness and efficiency were higher at the lower doses of gamma rays and EMS. The effectiveness of EMS treatments ranged from 1.09 to 4.55 . Results on mutagenic efficiency, calculated on the basis of percentage of survival reduction over control and seedling height reduction, showed that $2 \mathrm{kR}$ and $0.02 \mathrm{M}$ EMS were the most efficient treatments.

Similar results were reported by several authors in cowpea (Dhanavel et al., 2008), in lentil (Satpute 2009), in paprika (Kumar et al., 2012). In the present investigation lower concentration of EMS and gamma rays showed higher effectiveness values. In other words, the effectiveness of the mutagens decreased with increase in concentration of mutagens. Chemical mutagen (EMS) was found to be more effective than physical mutagen (gamma rays). It was also found that 
the lower concentration of both chemical and physical mutagens was the most effective. Sharma et al., (2005) also reported a higher mutagenic effectiveness at lower concentration or dose of EMS and gamma rays in urdbean. The decrease in effectiveness with increasing concentrations/doses of mutagen has been reported by Badere and Choudhary (2007) in linseed, Dhanavel et al., (2008) and Girija and Dhanvel (2009) in cowpea, Satpute (2009) in lentil and Barshile et al., (2006) in chickpea.

Results obtained during the present investigation revealed that highest mutation frequency and highest mutagenic efficiency of the mutagens were observed at lower dose of EMS $(0.02 \mathrm{M})$ and gamma rays $(2 \mathrm{kR})$ treatments. EMS was highly effective in enhancing the frequency of morphological mutants than gamma rays.

\section{Acknowledgments}

Fellowship provided by the University Grant Commission, New Delhi is duly acknowledged.

\section{References}

Badere, R.S. and Choudhry, A.D. 2007. Effectivity and efficiency of gamma rays, sodium azide and ethyl methanesulphonate in linseed. Bioinfolet, 4(3): 181-187.

Barcia MT, Jacques AC, Pertuzatti PB, Zambiazi RC, 2010. Determination by HPLC of ascorbic acid and tocopherols in fruits. Semina: Ciencias Agrárias (Londrina), 31(2):381-390.

Barshile, J.D., Auti, S.G., Dalve, S.C, and Apparao, B.J. 2006. Mutagenic sensitivity studies in chickpea employing SA, EMS and gamma rays. Indian J. Pulses Res., 19(1): 43-46.

Bukasov, S.M. 1963. Las plantas cultivadas de México, Guatemala y Colombia. IICA. Zona Andina. Publicación miscelánea, 20: 261.

Dhanavel, D.P., Pavada, L., Mullainathan, D., Mohana, G., Raju, M., and Thilagavathi, C. 2008. Effectiveness and efficiency of chemical mutagens in cowpea [Vigna unguiculata (L.) Walp]. African J. of Biotech., 7(22): 41164117.

Gaul, H., 1964. Mutation in plant breeding. Radiation Bot. 4: 155-232.

Gautam, A.S., Sood, K.C., and Richarria, A.K. 1992. Mutagenic effectiveness and efficiency of gamma-rays, ethyl methane sulphonate and their synergistic effects in black gram (Vigna mungo L.). Cytologia, 57(1): 85-89.

Girija, M. and Dhanvel, D. (2009). Mutagenic effectiveness and efficiency of gamma rays, EMS and their combined treatments in cowpea (Vigna unguiculata L. Walp.). Global J. Mol. Sci., 4(2): 68-75.

Gordon, S.A. and Webber, R.P. 1955. Studies on the mechanism of phytohormone Damage by Ionizing. I. The Radiosensitivity of Indoleacetic Acid. Plant Physiol, 30(3):200-10.

Gupta, P.K., 1996. Mutation breeding in mungbean. In A. N. Asthana and D.H. Kim (Eds.), Recent Adv. In Mungbean Res., pp. 124-136.

Gustaffson, A. 1940.The mutation system of the chlorophyll apparatus. Lunds Univ. Arsskr., 36:1-40.

Konzak, C.F., Nilan, R.A., Wagner, J. and Foster, R.J. 1965. Efficient chemical mutagenesis. The Use of Induced Mutations in Plant Breeding. (Rep. FAO/IAEA Tech. Meeting, Rome, 1964), Pergamon Press, pp. 49-70.

Kumar G.A., Ponnuswami, V. and Sundar, S.T.B. 2012. Effect of induced chlorophyll mutation, mutagenic efficiency and effectiveness of gamma 
rays and EMS in paprika (Capsicum annиuт L.) cv. Bydagi Kaddi. Indian J. Hort. 69(1): 60-64.

Mahabatra, B.K., 1983. Studies on comparative spectrum and frequency of induced genetic variability in green gram [Vigna radiata (L.) Wilczek]. Ph.D. Thesis, IARI, New Delhi.

Menzel, M.Y. 1951. The cytotaxonomy and genetics of Physalis. Proc. Amer. Phil. Soc., 95: 132-138.

Nilan, R.A. and C.F. Konzak, 1961. Increasing the efficiency of mutation breeding. Mutation and plant breeding. NAS-NRC, 891: 437-460.

Pawar, N., Pai, S., Nimbalkar, M., Kolar, F. and Dixit, G. 2010. Induction of chlorophyll mutants in Zingiber officinale Roscoe by gamma rays and EMS. Emir. J. Food Agric., 22(5):406411.

Puente, L.A., Pinto, S.A., Castro, E.S., and Cortés, M. 2011. Physalis peruviana L., The multiple properties of a highly functional fruit: a review. Food Res. I., 44: 1733-1740.

Satpute, R.A., 2009. Studies on the mutagenic effectiveness and efficiency of gamma rays in lentil. Bioinfolet, 6(2): 161-164.

Sharma S.K., Ritu S. and Pandey D.P. 2005.
Studies on mutagen sensitivity, effectiveness and efficiency in urd bean. Indian J. Genet., 65(1): 20-22.

Skoog, F. 1935. The effect of X-irradiation on auxin and plant growth. J. Cellular Comp. Physiol., 7: 227-270.

Solanki, I.S., and Sharma, B. 1994. Mutagenic effectiveness and efficiency of gamma rays, ethylene imine and $\mathrm{N}$ nitroso-N-ethyl urea in macrosperma lentil (Lens culinaris Medik.). Indian J. Genet., 54(1): 72-76.

Swaminathan, M.S., 1969. The role of mutation breeding in a changing agriculture. In: Induced mutations in Plants (Proc. Symp. Dullman, 1969), International Atomic Energy Agency, Vienna.

Wani, M.R., Khan, S., Kozgar, M.I., and Goyal S. 2011. Induction of morphological mutants in mugbean (Vigna radiata (L.) Wilczek) through chemical mutagens. The Nucleus, 48(3): 243-247.

Yamaguchi, H., Y. Hase, A. Tanaka, N. Shikazono, K. Degi, A. Shimizo, and T. Morishita. 2009. Mutagenic effects of ion beam irradiation on rice. Breed. Sci., 59: 169-177.

\section{How to cite this article:}

Alok Kumar Gupta, S.P. Singh, Manvendra Singh and Marboh, E.S. 2018. Mutagenic Effectiveness and Efficiency of Gamma Rays and EMS on Cape Gooseberry (Physalis peruviana L.). Int.J.Curr.Microbiol.App.Sci. 7(02): 3254-3260.

doi: https://doi.org/10.20546/ijcmas.2018.702.390 